This pdf contains:

Tacoli, C. 2009. "Crisis or Adaptation? Migration and Climate Change in a Context of High Mobility." Pp 104-118 in: Population Dynamics and Climate Change, edited by J.M.Guzmán, G. Martine, G. McGranahan, D. Schensul and C. Tacoli. New York: UNFPA; London: IIED.

The contents of the full book can be found here:

https://www.unfpa.org/public/publications/pid/4500

This pdf was downloaded from www.iied.org 


\title{
Crisis or Adaptation? Migration and Climate Change in a Context of High Mobility
}

\author{
Cecilia Tacoli
}

\section{Introduction}

The impact of climate change on population distribution and mobility is attracting growing interest and fuelling heated debate. Figures that are frequently cited estimate that, by 2050, the number of people forced to move primarily because of climate change will range between 200 million and 1 billion. ${ }^{1}$ Underlying these predictions is the view that migration reflects a failure to adapt to changes in the physical environment and that migrants are a relatively undifferentiated group all making similar emergency responses and moving to random destinations, including international ones. This is somehow at odds with the more nuanced view of migration as a key adaptive response to socio-economic, cultural and environmental change. From this perspective, the specific characteristics of migrant flows-duration, destination and composition-are essential to understanding their impact on sending and destination areas and to developing appropriate policies.

It is likely that both extreme weather events (storms, floods, heat waves) and changes in mean temperatures, precipitation and sea levels will in many cases contribute to increasing levels of mobility. However, there are inherent difficulties in predicting with any precision how climate change will impact on population distribution and movement. This is partly because of the relatively high level of uncertainty about the specific effects of climate change, and partly because of the lack of comprehensive data on migration flows, especially movements within national boundaries, in particular, for low-income countries that are likely to be most affected by climate change (Kniveton et al., 2008). Better information is important to formulate appropriate policy responses at the global level and at the local and national levels.

At the same time, policies that build on existing strategies to support adaptation to climate change are among the most likely to succeed. There is growing evidence suggesting that mobility, along with income diversification, is an important strategy to reduce vulnerability to environmental and non-environmental risks, including economic shocks and social marginalization. In many cases, mobility not only increases resilience but also enables individuals and households to accumulate assets. As such, it will probably play an increasingly crucial role in ad- 
aptation to climate change. Policies that support and accommodate mobility and migration are important for both adaptation and the achievement of broader development goals. However, in most cases, migration is still seen by many government and international agency staff as disruptive and requiring control and restrictive measures. The key argument of this chapter is that what is needed urgently is a radical change in perceptions of migration, as well as a better understanding of the role that local and national institutions need to play in making mobility a part of the solution rather than the problem.

\section{The Context: Policymakers' Perceptions of Migration}

There is a real risk that alarmist predictions of climate-change-induced migration will result in inappropriate policies that will do little to protect the rights of those most vulnerable to climate change (GECHS, 2008; Piguet, 2008). This is not surprising: As noted, migration is generally perceived as problematic, and most policies try to influence the volume, direction and types of movement rather than accommodate flows and support migrants.

Environmental factors affect patterns of migration and mobility within a broader context of important changes in population distribution. Perhaps the most widely acknowledged transformation is urbanization: It is estimated that, since 2008, half of the world's population is estimated to live in urban centres, and over 90 per cent of the world's population growth in the coming decades is expected to be in urban areas (United Nations, 2008b). This, of course, does not mean that all regions have similar levels or rates of urbanization. Moreover, while there is a strong statistical association between urbanization and economic growth, ${ }^{2}$ the scale of urban poverty in many low-income countries is growing rapidly; in many middle-income nations, the rate now exceeds rural poverty (Tacoli et al., 2008).

Rural-urban migration is often held responsible for the growth of urban populations and urban poverty. There is, however, little evidence to support such claims. According to available United Nations estimates, in the majority of the world's countries, natural population increase (the net excess of births over deaths in urban areas) makes a larger contribution than the combined effects of ruralurban migration and reclassification of settlements from rural to urban (United Nations, 2008a). ${ }^{3}$ Moreover, in most countries, rural migrants are not the majority of the urban poor (Montgomery et al., 2004), nor are they the only residents of low-income informal settlements (Tacoli et al., 2008). In addition, nations with the largest contributions of rural-to-urban migration to urban population growth are often the wealthiest or those with the most rapid economic growth.

Nevertheless, for most governments in low- and middle-income nations, migration has become a key policy issue and is perceived as a growing problem. A review of Poverty Reduction Strategy Papers of countries across Africa shows the depth of negative perceptions of migration, which is seen as putting pressure on urban areas, promoting the spread of crime and HIV/AIDS, stimulating land degradation and contributing to both urban and rural poverty (Black et al., 2006). 
Between 1996 and 2003, the proportion of governments in low- and middle-income countries that implemented policies to influence internal migration grew from 51 to 73 per cent (United Nations, 2004). Most of these measures have had little success, however, and have often resulted in increasing hardships for the urban poor (UNFPA, 2007; United Nations, 2008a). They also overlooked the fact that most migrants do better than those who remain in rural areas and that their remittances are an important component of the budgets of rural households. Plans intended to tackle the possible impacts of climate change on population distribution need to take into account a policy context that does not generally recognize or support the positive potential of migration.

Despite the importance of urbanization, it is misleading to assume that ruralurban migration is the predominant direction of movement within countries. To a large extent, the direction of migration flows reflects a country's level of urbanization (the proportion of its population residing in areas classified as urban) and the nature of its economic base. Rural-rural migration is prevalent in agriculture-based economies, such as in many low-income African nations, while urban-urban movement is more important in regions with high levels of urbanization, such as much of Latin America and the Caribbean. Rural-urban migration tends to be high in areas with high levels of economic growth and expanding industry and service sectors, but even in countries such as India and Viet Nam, rural-rural migration flows are also large. In Viet Nam, 37 per cent of the migration captured by the 1999 census was among rural areas, compared to 26 per cent among urban centres, 10 per cent from urban to rural areas and 27 per cent rural to urban. In India, 38 per cent of recent migrants were estimated to move among rural areas (Skeldon, 2003). Rural-rural migration tends to be dominated by the poorest groups, who often do not have the skills, financial capital or social networks to move to urban centres.

It is also misleading to assume that migration from poor to rich countries is the predominant form of movement. International migration only accounts for a small proportion of all movement and much of it is within regions rather than towards high-income countries. At the global level, however, it is often assumed that climate-change-related migration will be across borders, and from poor to rich countries. Given the contradictory stances toward international migration in destination countries-where the acknowledged need for migrant labour often goes hand in hand with attempts to curtail arrivals, especially from low-income countries-it is not surprising that the prospect of millions of climate refugees landing on the shores of rich countries is seen with alarm. In March 2008, the European Union High Representative for foreign and security policy, Javier Solana, warned that "such migration may increase conflict in transit and destination areas. Europe must expect substantially increased migratory pressure” (Solana, 2008).

\section{Climate Change Migrants: The Debate and the Evidence}

The relationship between climate change and migration has been rightly defined as "complex and unpredictable" (Brown, 2008), and the scarcity of reliable 
evidence on the topic has contributed to the heated and highly politicized discussion on the potential existence of environmental refugees, as well as predictions on their numbers. The term 'environmental refugee'-people forced to move because of environmental degradation resulting from climate change-was first formally used in the 1970s and was heavily influenced by the neo-Malthusian assumption that population growth would lead to migration and conflict caused by resource scarcity. Such views were not supported by evidence, and environmental pressure as a fundamental cause of migration was generally downplayed until recently, when increased attention to the impacts of climate change refuelled the debate (Massey et al., 2007; Morrissey, 2009; Zolberg, 2001).

The most frequently cited figure predicts that, by 2050 , there could be as many as 200 million environmental refugees (Myers, 2005; Stern Review Team, 2006). It is surprising that this has become an unquestioned orthodoxy, especially among natural scientists concerned with climate change, in view of the widespread criticisms of both the figure and its conceptual underpinnings, and perhaps even more so given the growing consensus on the importance of multiple and overlapping causes of most migration flows, including economic, social and political factors (Castles, 2002; GECHS, 2008; Hugo, 2008; Morrissey, 2009; Piguet, 2008). This recognition is reflected in the changing focus of the reports of the Intergovernmental Panel on Climate Change (IPCC) from an earlier emphasis on human migration to the current stress on population vulnerability and capacities to adapt to climate change (Raleigh et al., 2008).

The key problem with the concept of environmental refugees is the implicit assumption that there is a direct causal link between environmental change and migration. The figure proposed is an estimate of the numbers of people at riskthat is, of the populations living in areas most likely to be affected by the negative impacts of climate change-rather than the number of people who are in fact likely to move (Castles, 2002). This over-simplified view is based on 'common sense' rather than on an understanding of the complex relationship between environmental change (and perceptions of it) and human agency, which includes adaptation that reduces the need to move away from affected areas, as well as the multiple factors that affect migration decisions. It also overlooks the fact that migration requires financial resources and social support, both of which may decline with climate change, thus resulting in a reduction, rather than an increase, in the number of people able to move.

There is also little evidence that people who have already been exposed to environmental degradation actually do move in the ways and numbers predicted by the environmental refugees' model. New research and reviews of existing information (for example, Brown, 2008; Hugo, 2008; Morrissey, 2009; Piguet, 2008; Raleigh et al., 2008) are building a clearer picture of how climate change may affect migration. Predicting future climate change, however, is inherently uncertain. For example, while global warming in the $21^{\text {st }}$ century will be more intense in Africa than in the rest of the world (with average temperature rise 1.5 times greater than at the global level), the results of rainfall projections remain uncertain, and no conclusions can be 
drawn for West Africa (ECOWAS/SWAC, 2008). This clearly makes understanding and predicting the impacts of climate change on human societies extremely difficult, especially the long-term impacts that can be mediated by adaptive capacities. With this in mind, the best approximation-with all its limitations-is to use the experiences of past and current events as analogous to climate-change-induced drought, desertification and land degradation, extreme weather events such as floods and hurricanes and, obviously to a much lesser extent, sea level rise.

\section{Drought, desertification and land degradation}

Freshwater availability is predicted to decrease and to affect between 75 and 250 million people in Africa by 2020, and up to a billion people in Asia by 2050 (IPCC, 2007). These figures represent the number of people living (or, more often, estimated to live) in areas at risk, but not necessarily those directly affected by water shortages. It is important to note that water stress does not necessarily imply inadequate access to water for domestic purposes, especially for urban households. Statistically, households in countries facing water stress are no more likely than those in other countries to lack access to improved water supplies. There is also considerable case-specific evidence of cities with plentiful water resources where poor households do not have adequate access to affordable water and cities with scarce water resources where poor households are comparatively well served (McGranahan, 2002). Decreases in rainfall can, however, affect people in economic terms, for example, through a decline in agricultural productivity, and thus be a contributing factor to mobility.

The links between drought, desertification and migration are complex, and much of the existing literature draws on analogies with the drylands areas of Africa, where climatic fluctuations, as well as widespread mobility, have always been a defining feature. Research in northern Mali in the late 1990s found that up to 80 per cent of households interviewed had at least one migrant member, but this high level of mobility was related more to the pursuit of economic opportunities and the need to diversify income sources than a direct consequence of desertification and land degradation (GRAD, 2001). In the same region, the drought of 1983-1985 affected local migration patterns, with an increase in temporary and short-distance movement and a decrease in long-term, intercontinental movement (Findley, 1994). Recent research in Burkina Faso suggests that a decrease in rainfall increases rural-rural temporary migration; on the other hand, migration to urban centres and abroad, which entails higher costs, is more likely to take place after normal rainfall periods and is influenced by migrants' education, the existence of social networks and access to transport and roads (Henry et al., 2004). These findings mirror those of research in other contexts: In Nepal, land degradation and environmental deterioration lead mainly to local movements, although the better educated tend to move to urban centres farther away (Massey et al., 2007).

These overall patterns also vary depending on individual and household circumstances. Gender is an important variable determined by the locally prevailing 
gender relations and divisions of labour. Hence, since marriage is their main reason to move, women in the Sahel are less likely than men to engage in short-term movement (Henry et al., 2004). In Nepal, where women have primary responsibility for agricultural production, they are significantly less likely than men to move to distant destinations (Massey et al., 2007). The migration patterns of wealthier, better educated and better socially connected groups seem to be relatively unaffected by environmental degradation. Younger, landless households with few dependents are more likely to move permanently than those who own land and property in the affected area (Massey et al., 2007; McLeman and Smit, 2004). However, impoverished groups with limited resources to invest in migration are less likely to move, and their ability to cope will be increasingly determined by the availability of locally based opportunities for income diversification.

The impacts of slow-onset climate change are also more likely to affect politically and economically marginalized groups, especially where local institutions are unable to mediate growing competition for resources. Pastoralist groups have long developed strategies to cope with unpredictable environments, and mobility of families or parts of families for pastoral production, including seasonal transhumance and travel to markets, is a key element of such strategies. However, decreasing rainfalls and more frequent droughts will put more pressure on pastoral resources, pushing pastoralists further away from their traditional migratory routes. It is often thought that this, in turn, will increase conflict between nomadic pastoralists and sedentary farming communities over dwindling resources, and Darfur is often cited as an example. However, in this case-and probably in many others-conflict is the result of a combination of environmental pressures and the breakdown of traditional social structures and well-established local mediation and dispute resolution mechanisms (Edwards, 2008). Throughout drylands Africa, years of political and economic marginalization of pastoralist groups, inappropriate development policies constraining mobility, much lower access to basic services than national averages and limited opportunities for income diversification have been important factors in the propensity of pastoralists to migrate to urban centres (Hesse and Cotula, 2006; Oxfam International, 2008). Changes in traditional migratory routes and migration to seek alternative livelihoods are valid responses to changing environmental contexts, and both need to be better supported.

\section{Extreme weather events}

In many cases, floods and hurricanes, especially when accompanied by landslides, force people to leave their homes and move to other areas. Displaced people are often extremely vulnerable, and, in most cases, experience shows that they return as soon as possible to reconstruct their homes and livelihoods (Perch-Nielsen and Bättig, 2005; Piguet, 2008; Raleigh et al., 2008). Extreme events only become disasters when they affect populations with high levels of vulnerability. Repeated events and limited access to government and non-governmental support systems are important factors in increasing risk. This is not only the case for low- and 
lower-middle income countries: Poor communities in New Orleans, for example, were much more affected by Hurricane Katrina than wealthier groups, partly because of the location and conditions of their houses, and partly because of lack of insurance. As a result, poor groups were the majority of permanent out-migrants from the city (Morrissey, 2009). In contrast, in the aftermath of the Indian Ocean Tsunami in 2004, out-migration was limited, and mass migration never occurred. This is attributed to a variety of factors, not least of which is the rapid humanitarian response and the substantial mobilization of diaspora groups to support victims at home (Naik et al., 2007). Similarly, a study of the impact of the 14 April 2004 tornado in Bangladesh found that it had little if any consequences on outmigration from the affected areas, as aid and recovery packages were distributed rapidly and fairly, and the event itself was perceived as exceptional and unlikely to occur again (Paul, 2005).

The importance of effective coping strategies by communities and governments is illustrated by the different impacts of two natural disasters. After the Kobe earthquake in Japan in 1995, 300,000 people were displaced, but, within three months, only 50,000 had not returned home; in contrast, many of the people displaced by the eruption of Mount Pinatubo in the Philippines in 1991 were still in temporary camps or squatter settlements after several years (Castles, 2002).

\section{Sea level rise}

Sea level rise is a long-term, gradual process of inundation and is also a contributor to the severity of storm surges and flooding. This makes it a major threat for the inhabitants of small island states, especially those with low elevation above sea level, and also for those living in flood plains close to the sea or tidal rivers or those living in cyclone-prone coastal zones. Over 600 million people (10 per cent of the world's population) are estimated to live in coastal zones with an elevation of up to 10 metres (about 2 per cent of the world's land area). Of these, 360 million live in urban areas (13 per cent of the world's urban population), and about 247 million live in low-income countries (McGranahan et al., 2007). Obviously, the actual number at risk from sea level rise and storm surges over the next few decades is probably smaller than this, but there are no reliable figures for the numbers or proportions of people living in coastal areas lower than 10 metres above sea level. Whether migration will be the main response to sea level rise will depend on the capacity of communities and governments to respond with a range of options, such as increased protection infrastructure, the modification of land use and construction technologies and managed retreat from highly vulnerable areas (Perch-Nielsen, 2004). Ironically, some of the areas most at risk are also major migrant destinations since they offer better economic opportunities through their concentration of industry and services. Measures to support a more decentralized pattern of urbanization and industrialization would help reduce the numbers of people living in areas at risk and, at the same time, reduce regional inequalities that are a root cause of migration. 
In summary, research on contexts that offer similarities to the situations predicted for the impacts of climate change suggest that environmental degradation does not inevitably result in migration. Where it does, it is likely that movement is predominantly short term, as in the case of extreme weather events and natural disasters, and short-distance, as in the case of drought and land degradation. In the case of rising sea levels, much less can be inferred from past experience, and the number of people forced to move will depend on adaptation initiatives as well as on wider national planning strategies. The significance of non-environmental factors in migration, the uncertainty of the extent of changes in rainfall patterns and tropical cyclone/hurricane/typhoon frequency and strength as a consequence of climate change, and the fact that predictions only go as far as the next 50 years, are serious limitations for any realistic long-term assessment of the link between climate change and migration. At the same time, however, there are clear pointers to the need to understand migration as one in a range of strategies that individuals and households can use to adapt to climate change.

\section{Income Diversification and Circular Mobility as an Adaptive Response to Slow-onset Climate Change}

The prevalence of short-distance, circular migration as a result of land degradation and desertification, especially in areas relying primarily on rainfed agriculture, is effectively a form of income diversification that may involve the same activityfarming-in other locations, or temporarily engaging in non-farm activities, especially when less labour is required in the fields. Household members may also move to urban centres, especially where there is demand for migrant labour, and send home remittances on a regular basis. It can be expected that, based on existing patterns and trends, such income diversification will become an increasingly important element of adaptation to slow-onset climate change.

There is little research that directly explores the impact of environmental factors on income diversification and mobility. However, there is much evidence showing that these interrelated strategies are substantial elements of the livelihoods of both rural and urban populations. In China, for example, a 1994 survey by the Ministry of Agriculture suggested that non-farm incomes and internal transfers from rural migrants to urban centres were about to overtake earnings from agriculture in rural household budgets (Deshingkar, 2006). In India, remittances accounted for about one third of the annual incomes of poor and landless rural households (Deshingkar, 2006). Earnings from non-farm activities were also substantial and were estimated to account for between 30 and 50 per cent of rural households' incomes in Africa, reaching as much as 80-90 per cent in Southern Africa, about 60 per cent in Asia (Ellis, 1998) and around 40 per cent in Latin America (Reardon et al., 2001). In Bangladesh, between 1987/1988 and $1999 / 2000$, income from agriculture declined from 59 to 44 per cent of rural households' budgets, while income from trade, services and remittances grew from 35 to 49 per cent (Afsar, 2003). 
Remittances and earnings from non-farm activities have proved to play a major role in financing innovation and intensification of farming in Africa (Tiffen, 2003) and in Asia (Hoang et al., 2005; Hoang et al., 2008). On the one hand, income diversification provides the capital needed to invest in agricultural productioninputs, infrastructure and sometimes waged labour. On the other hand, income diversification also provides the safety net that enables farmers to take the risks inherent in changing long-held practices. As such, it is an essential element of agricultural adaptation to climate change.

The extent of temporary, circular and seasonal migration that often underpins income diversification is usually underestimated. In part, this is because these movements tend to elude national statistics and census data. However, estimates suggest that the numbers involved are striking. In Thailand, one third of all internal migration in the early 1990s was estimated to consist of temporary movement to Bangkok's metropolitan region during the dry season, when labour demand for agricultural work decreases (Guest, 1998). In India, an estimated 20 million people migrate temporarily each year (Deshingkar, 2006). Most of this movement is between rural drought-prone regions to rural areas of irrigated agriculture which require seasonal labour. There are, however, signs that the combination of agricultural mechanization and demand for unskilled and semi-skilled workers in the construction sector is re-orienting migrants towards urban centres and non-farm occupations. In northern Bihar, for example, temporary movement to urban centres has grown from 3 per cent of the total in 1983 to about 24 per cent in 2000 (Deshingkar, 2006).

The preference for urban destinations supports the view that increasing numbers of short-term migrants opt for employment in non-farm activities. In Burkina Faso, circular movement involving returning to home areas within two years is especially high among those engaging in cross-border migration but also applies to ruralurban migrants and, to a lesser extent, rural-rural migrants (Henry et al., 2004). In Viet Nam's Red River Delta, it is increasingly common for farmers to move to urban centres to work in the construction sector for a few months every year and then return to their villages (Hoang et al., 2005). In China, in 1999, about 60 per cent of registered migrants in the industrial and construction hubs in the coastal region had lived in their current place of residence for less than one year, and only between 15 and 30 per cent intended to settle there permanently (Zhu, 2003).

In urban centres in Africa, research shows that both wealthy and poorer groups tend to invest in property in rural areas, often their home villages, as a safety net against economic and political crises (Kruger, 1998; Smit, 1998). Recognizing these investments and ensuring that both short- and long-term migrants retain rights in their home areas is important, especially for the groups most vulnerable to loss of property and incomes. The current economic downturn is showing just how important this is: In February 2009, the Chinese Government estimated that 20 million, or 15.3 per cent of its rural-urban migrant workers, had been forced to return to the countryside because of job losses linked to the global economic downturn (Xinhua News, 2009). Rural safety nets also proved to be critical for 
urban residents in many African countries during the 1990s and have certainly facilitated return urban-rural movements (Jamal and Weeks, 1988; Potts and Mutambirwa, 1998).

Employment insecurity, the high cost of living and often unsafe and insecure accommodation in urban centres arguably act as contributing factors to circular migration and combine with environmental degradation in home areas in increasing people's mobility. The spatial distribution of economic opportunity will, however, remain the key determinant of migration directions, as well as a primary focus for policy action.

\section{Accommodating and Supporting Mobility: Small Urban Centres and Institutions}

Since climate stress almost invariably overlaps with socio-economic, political and cultural factors in determining migration duration, direction and composition, these other factors need to be integrated in adaptation policies. Moreover, agricultural adaptation initiatives should not assume that they ought to contribute to reducing out-migration-especially rural-urban migration-as there is ample evidence to show that rural development usually has little effect on migration and, where it does, it tends to encourage rural-urban migration (Beauchemin and Bocquier, 2004; Deshingkar, 2004; Henry et al., 2004; Hoang et al., 2008; Massey et al., 2007). This does not mean that rural development should not be a priority, especially when the majority of the population lives in rural areas. Broader agricultural and rural development, and specific climate change adaptation actions to support these, should not be linked to the reduction of migration. Changing opportunities in urban centres as a result of economic downturns are more likely to affect migration patterns, as is currently the case.

Environmental degradation will in all probability contribute to the growing need to ensure access to non-farm economic activities, either locally or involving some level of mobility. In many cases, local small towns or large villages are where these activities are concentrated. Indeed, the potential role of small and intermediate urban centres in economic growth, poverty reduction and, more recently, adaptation to the impacts of climate variability has been attracting the attention of policymakers since the 1960s. Small towns in agricultural areas are especially important for the livelihoods of the poorest groups, who are often landless and without the means to migrate to larger cities, by providing access to non-farm activities that require limited skills and capital (Hoang et al., 2008). They also play an important role in the provision of basic services such as health and education to their own population and to that of the surrounding rural area. This is likely to become increasingly important because of slow-onset climate change and the increase in the frequency and intensity of extreme events. Moreover, small and intermediate urban centres are essential components of national policies that aim to achieve a more decentralized pattern of urbanization across regions-and this is especially important in view of the concentration of 
large cities in low elevation coastal zones that are vulnerable to sea level rise (McGranahan et al., 2007).

Many of the policies instituted for small-town and regional development since the 1960s, however, have had very limited success, partly because of their topdown nature that neglected the importance of local characteristics and partly because they overlooked the critical importance of national macroeconomic policies in local development (Satterthwaite and Tacoli, 2003). Hence, while small towns can play a crucial role in adaptation to climate change, this can only be achieved within a broader approach to development and poverty reduction. Local small and microenterprises-in most cases the backbone of small towns' economies and where low-income groups are concentrated-need access to markets, outside capital resources and technical knowledge. As important market nodes for agricultural production, small town traders are essential for smallholder farmers; however, they cannot replace access to the land, credit and inputs that enable family farmers to respond to changes in demand (Satterthwaite and Tacoli, 2003). Perhaps most important, local governments in small towns in too many cases lack the capacity, resources and support from higher-level government.

One area where local governments in small towns need to improve their capacity is in the provision of services to migrants and the protection of their rights. Poor migrants in smaller urban centres can be more disadvantaged than migrants in the large cities because of the limited existence of the civil society organizations that can support their interests. Hence, migrants are often paid less by their employers than non-migrants, partly because they may not be aware of the prevailing wages and they are usually not members of workers' unions and associations (Deshingkar et al., forthcoming). In many instances, their willingness to accept lower wages may put them at odds with non-migrants, resulting in further marginalization and increased exposure to occupational health hazards (Hasan and Raza, 2009). They are also less likely to be able to access public services that require registration with local authorities, such as ration cards in India. At the same time, they are often registered on voters' lists and are manipulated by local politicians who do not represent their needs and priorities (Deshingkar et al., forthcoming). Overall, however, whether in large cities or in small towns, poor temporary migrants share many of the vulnerabilities of the urban poor. Perhaps the main difference is that they tend to be even less visible and therefore have even less political representation and voice.

\section{Conclusions}

Predicting the impact of climate change on population distribution and movement is fraught with difficulties. However, it seems unlikely that the alarmist predictions of hundreds of millions of environmental refugees will translate into reality. What is more likely is that the current trends of high mobility, linked to income diversification, will continue and intensify. Past experiences suggest that short-distance and short-term movements will probably increase, with the very 
poor and vulnerable in many cases unable to move. Underlying these trends is the growing need for the diversification of income sources and the spatially unequal distribution of economic opportunities. The centrality of both of these issues to adaptation initiatives cannot be over-emphasized. What is also necessary is a radical change in the perceptions of migration. Most migration management policies try to influence the volume, direction and types of population movement. However, policies might more usefully aim at accommodating the changes in migration patterns that result from environmental degradation, economic growth or crisis and other, wider transformations. This seems to be an essential element of adaptation to climate change and other development goals.

\section{Notes}

1 The 200 million figure is from Norman Myers (2005); the 1 billion figure is from Christian Aid (2007).

2 There is also a strong statistical association between urbanization and increases in the proportion of GDP generated by industry and services and the proportion of the labour force working in these sectors.

3 There are exceptions, and these include some of the most populous countries in the world, notably China and Indonesia (United Nations, 2008a).

\section{References}

Afsar, R. 2003. "Internal Migration and the Development Nexus: the Case of Bangladesh." Paper presented at the Conference on Migration, Development and Pro-Poor Policies in Asia, Dhaka, Bangladesh, 22-24 June 2003.

Beauchemin, C., and P. Bocquier. 2004. "Migration and Urbanisation in Francophone Africa: An Overview of the Recent Empirical Evidence.” Urban Studies 41(11): 2245-2272.

Black, R., et al. 2006. Migration and Development in Africa: An Overview. Migration and Development Series. No. 1. Cape Town, South Africa, and Kingston, Ontario: Southern African Migration Project.

Brown, O. 2008. Migration and Climate Change. IOM Migration Research Series. No. 31. Geneva: International Organization for Migration.

Castles, S. 2002. Environmental Change and Forced Migration: Making Sense of the Debate. New Issues in Refugee Research Working Paper. No 70. Geneva: UNHCR.

Christian Aid. 2007. Human Tide: The Real Migration Crisis. A Christian Aid Report. London: Christian Aid.

Deshingkar, P. 2006. "Internal Migration, Poverty and Development in Asia." Paper presented at the conference, Asia 2015: Promoting Growth, Ending Poverty, London, 6-7 March 2006.

2004. “Improved Livelihoods in Improved Watersheds: Can Migration Be Mitigated?” Paper presented at the International Workshop on Watershed Management Challenges, New Delhi, India, organized by the Indian Council of Agricultural Research, International Water Management Institute, and International Crops Research Institute for the Semi-arid Tropics, 3-4 November 2004.

Deshingkar, P., et al. Forthcoming. Governance for Local Development in Small Towns: Addressing the Challenges and Opportunities of Increasing Migration and Mobility in India. Rural-Urban Working Paper. No. 18. London: International Institute for Environment and Development (IIED).

ECOWAS/SWAC/OECD. 2008. Climate and Climate Change. Atlas on Regional Integration in West Africa Environment Series. Abuja and Paris: Economic Community of West Africa, and Sahel and West Africa Club/ Organisation for Economic Co-operation and Development.

Edwards, S. 2008. “Social Breakdown in Darfur.” Forced Migration Review, Issue No. 31, pp. 23-24. 
Ellis, F. 1998. "Livelihood Diversification and Sustainable Rural Livelihoods." Ch. 4 in: Sustainable Rural Livelihoods: What Contribution Can We Make, edited by D. Carney. 1998. London: Department for International Development.

Findley, S. 1994. "Does Drought Increase Migration? A Study of Migration from Rural Mali during the 19831985 Drought.” International Migration Review 28(3): 539-553.

GECHS (Global Environmental Change and Human Security). 2008. Disaster Risk Reduction, Climate Change Adaptation and Human Security. Report 2008:3. Oslo: University of Oslo.

GRAD (Groupe Recherche Actions pour le Développement). 2001. Potentialités et conflits dans les zones péri-urbaines: le cas de Mopti an Mali. Rural-Urban Working Paper. No. 6. London: IIED.

Guest, P. 1998. "Assessing the Consequences of Internal Migration: Methodological Issues and a Case Study on Thailand based on Longitudinal Survey Data." Pp.275-318 in Migration, Urbanization and Development: New Directions and Issues, edited by R. Bilsborrow. 1998. New York: UNFPA and Kluwar Academic Publishing.

Hasan, A., and M. Raza. 2009. Migration and Small Towns in Pakistan. Rural-Urban Working Paper. No. 15. London: IIED.

Henry, S., B. Schoumaker, and C. Beauchemin. 2004. "The Impact of Rainfall on the First Out-Migration: A Multi-level Event-History Analysis in Burkina Faso.” Population and Environment 25(5): 423-460.

Hesse, C., and L. Cotula. 2006. Climate Change and Pastoralists: Investing in People to Respond to Adversity. Sustainable Development Opinion Papers. London: IIED.

Hoang, X. T., A. N. Dang, and C. Tacoli. 2005. Livelihood Diversification and Rural-urban Linkages in Vietnam's Red River Delta. Rural-Urban Working Paper. No 11. London: IIED.

Hoang, X. T., et al. 2008. Urbanization and Rural Development in Viet Nam's Mekong Delta: Livelihood Transformations in Three Fruit-growing Settlements. Rural-Urban Interactions Working Paper. No. 14. London: IIED.

Hugo, G. 2008. Migration, Development and Environment. IOM Migration Research Series. No. 35. Geneva: IOM.

IPCC. 2007. Summary for Policy Makers. A Report of the Working Group of the Intergovernmental Panel on Climate Change. Geneva: IPPC.

Jamal, V., and J. Weeks. 1988. "The Vanishing Rural-urban Gap in Sub-Saharan Africa." International Labour Review 127(3): 271-292.

Kniveton, D., et al. 2008. Climate Change and Migration: Improving Methodologies to Estimate Flows. IOM Migration Research Series. No 33. Geneva: IOM.

Kruger, F. 1998. "Taking Advantage of Rural Assets as a Coping Strategy for the Urban Poor: The Case of Ruralurban Interrelations in Botswana." Environment and Urbanization 10(1): 119-134.

Massey, D., W. Axinn, and D. Ghimire. 2007. Environmental Change and Out-Migration: Evidence from Nepal. Population Studies Center Research Report. No. 07-615. Ann Arbor, MI: Institute for Social Research, University of Michigan.

McGranahan, G. 2002. Demand-Side Water Strategies and the Urban Poor. Poverty, Inequality and Environment Series. No. 4. London: International Institute for Environment and Development.

McGranahan, G., D. Balk, and B. Anderson. 2007. "The Rising Tide: Assessing the Risks of Climate Change and Human Settlements in Low Elevation Coastal Zones.” Environment and Urbanization 19(1): 17-37.

McLeman, R., and B. Smit. 2004. Commentary No. 86: Climate Change, Migration and Security. Ottawa: Canadian Security Intelligence Service.

Montgomery, M. R., et al. (eds.) 2004. Cities Transformed: Demographic Change and Its Implications in the Developing World. Washington, D. C.: National Academic Press. 
Morrissey, J. 2009. Environmental Change and Forced Migration: A State of the Art Review. Oxford: Refugee Studies Centre, Oxford Department of International Development, University of Oxford.

Myers, N. 2005. "Environmental Refugees: An Emerging Security Issue.” Paper presented at the 13th Economic Forum, Organization for Security and Co-operation in Europe, Prague, 23-27 May 2005.

Naik, A., E. Stigter, and F. Laczko. 2007. Migration, Development and Natural Disasters: Insights from the Indian Ocean Tsunami. IOM Migration Research Series. No 30. Geneva: IOM.

Oxfam International. 2008. Survival of the Fittest: Pastoralism and Climate Change in East Africa. Oxford: Oxfam Briefing Paper.

Paul, B. K. 2005. "Evidence against Disaster-induced Migration: The 2004 Tornado in North-central Bangladesh." Disasters 29(4): 370-385.

Perch-Nielsen, S. 2004. "Understanding the Effect of Climate Change on Human Migration: The Contribution of Mathematical and Conceptual Models.” Diploma thesis. Zurich: Department of Environmental Studies, Swiss Federal Institute of Technology.

Perch-Nielsen, S., and M. Bättig. 2005. "Exploring the Link between Climate Change and Migration.” Paper presented at the 6th Open Meeting of the Human Dimensions of Global Environmental Change Research Community, Bonn, 9-13 October 2005.

Piguet, E. 2008. Climate Change and Forced Migration. New Issues in Refugee Research Series, Research Paper No. 153, Geneva: UNHCR.

Potts, D., and C. Mutambirwa. 1998. “'Basics are Now a Luxury': Perceptions of Structural Adjustment's Impact on Rural and Urban Areas in Zimbabwe.” Environment and Urbanization 10(1): 55-75.

Raleigh, C., L. Jordan, and I. Salehyan. 2008. "Assessing the Impact of Climate Change on Migration and Conflict.” Paper commissioned for the Social Dimensions of Climate Change Workshop, Social Development Department, the World Bank, Washington, D.C., 5-6 March 2008.

Reardon, T., J. Berdegué, and G. Escobar. 2001. "Rural Nonfarm Employment and Incomes in Latin America: Overview and Policy Implications.” World Development 29(3): 395-409.

Satterthwaite, D., and C. Tacoli. 2003. The Urban Part of Rural Development: The Role of Small and Intermediate Urban Centres in Rural and Regional Development and Poverty Reduction. Rural-Urban Interactions Working Paper Series. No 9. London: IIED.

Skeldon, R. 2003. "Migration and Migration Policy in Asia: A Synthesis of Selected Cases." Paper presented at the Conference on Migration, Development and Pro-Poor Choices in Asia, Dhaka, Bangladesh, 22-24 June 2003.

Smit, W. 1998. “The Rural Linkages of Urban Households in Durban, South Africa.” Environment and Urbanization 10(1): 77-87.

Solana, J. 2008. Climate Change and International Security: Paper from the High Representative and the European Commission to the European Council. Brussels: European Commission.

Stern Review Team. 2006. The Economics of Climate Change? Discussion paper. London: HM Treasury.

Tacoli, C., G. McGranahan, and D. Satterthwaite. 2008. "Urbanization, Poverty and Inequity: Is Rural-Urban Migration a Poverty Problem, or Part of the Solution.” Pp. 37-53 in: The New Global Frontier: Urbanization, Poverty and Environment in the 21st Century, edited by G. Martine, et al. 2008. London: Earthscan.

Tiffen, M. 2003. "Transition in sub-Saharan Africa: Agriculture, Urbanization and Income Growth." World Development 31(8): 1343-1366.

UNFPA. 2007. The State of World Population 2007: Unleashing the Potential of Urban Growth. New York: UNFPA.

United Nations. 2008a. An Overview of Urbanization, Internal Migration, Population Distribution and Development in the World. New York: Population Division, Department of Economic and Social Affairs, United Nations. 
2008b. World Urbanization Prospects: The 2007 Revision (POP/DB/WUP/Rev.2007). New York: Population Division, Department of Economic and Social Affairs, United Nations.

2004. World Population Policies 2003. New York: Population Division, Department of Economic and Social Affairs, United Nations.

Xinhua News. 2 February 2009. "20 Million Jobless Migrant Workers Return Home.” Website: http://news. xinhuanet.com/english/2009-02/02/content_10750749.htm, accessed 18 March 2009.

Zhu, Y. 2003. “The Floating Population's Household Strategies and the Role of Migration in China's Regional Development and Integration.” International Journal of Population Geography 9(6): 485-502.

Zolberg, A. R. 2001. "Introduction: Beyond the Crisis.” Pp. 1-16 in: Global Migrants, Global Refugees: Problems and Solutions, edited by A. R. Zolberg and P. M. Benda. 2001. New York and Oxford: Berghahn Publishers. 